\title{
Economic and Social Impact of Advanced Research at Universities
}

\author{
Sergey V. Ketov \\ Tokyo Metropolitan University, Tokyo, Japan
}

\begin{abstract}
The major purpose of any university is high-quality education of its students for the needs of society. Qualified staff (including teachers and administration) is the necessary condition for high-quality education of students. The qualified staff (university teachers) can only be internationally competitive when they do high quality research andactively participate in the university management. Government and industry set up the "boundary conditions" for universities, but they should not interfere into the internal self-governance of the universities, and should respect academic freedom. A world-class university has its own Triple Helix uniting education, research and innovation. A few specific examples of practical realization of such "sub" Triple Helix are given, which are based on personal experience of the author during 24 years of his work as a professor at leading universities in the USA, Germany and Japan. Though some findings and conclusions may have limited use in any particular country, there are universal features that should be present in any modern university interested in increasing its impact on local environment, concerned with interaction to local government and local businesses, and striving for top positions in international rankings.
\end{abstract}

keywords: university, education, research, innovation

\section{Introduction}

The author is not qualified to discuss the original concept of the Triple Helix, in the interface among university, industry, and government (Etzkowitz, 2008). However, The author is well qualified to address one corner of it, namely, the "university". Moreover, In this paper the original concept of Triple Helix inside a moder nuniversity is proposed and illustrated on a number of specific examples.

To begin with an observation. During his 12-years-old tenure at the Tokyo University the author never had business with the University President, except of his very first day in the job. And that is also true for a vast majority of professors in our University in Tokyo. Dealing with Tokyo government and communicating it policies back to the university is the main job of our University President. However, our university itself has so high degree of self-organization and self-governance that the first person (president or rector) is essentially irrelevant in the university's daily life for almost everyone (just compare that with any university in Russia!). High autonomy of a university is essential for high standards of teaching and research, including advanced education of professionals, scientists, and entrepreneurs in the competitive environment of "beautiful minds" and academic freedom.

Of course, no university can be fully independent just because it needs to be financially supported. It is all about its internal academic freedom subject to the boundary conditions imposed by society. A society needs

Sergey V. Ketov, Dr. rer. nat. habil., Professor, Physics Department, Tokyo Metropolitan University. 
universities for its "tomorrow" by educating students. But it also needs universities "today" as a source for its intellectual, technological, and social development.

One may be surprised by the remark that many basic things like "universities exist for their students and professors" tend to be forgotten, even inside the universities themselves. One of the reasons is that even at the top universities excellence in teaching is not highly regarded in practice. Hiring new faculty is usually rated by excellence in research, not in teaching. Many university professors consider teaching more as a burden rather than a target because they have little incentives for spending more time for teaching rather than for research and administration. It sometimes results in auniversity for its staff rather than a university for its students.

The related problem on the student's side is just study for credits and graduation, not for knowledge and skills. In opinion of the author, government hardly can help here because it is too far from the university's life, is often too bureaucratic and inflexible. Industry may help but it is often too much oriented for profit and its needs for "today". However, universities are supposed to train students for "tomorrow", so that they ought to be much more future-oriented.

It is, therefore, important to understand what are the most fundamental challenges faced by universities now, and how should the universities modernize themselves, in order to meet those challenges.

\section{Triple Helix Inside a University}

Being a representative of natural sciences, the author go this major experience in research and teaching of physics and mathematics. He is also actively involved into internal self-management at the Metropolitan University in Tokyo, dealing with subscription of international scientific journals, inviting prominent scientists and facilitating accommodation of international students. The author used to run a seminar (once a week) mainly to the first year students of the Departments of Lawand Economics about globalization, and it had nothing to do with natural sciences. The author has MBA degree of a German university, and also co-founded three private enterprises in Germany in the past that gave him valuable experience in private business too.

In the author's opinion, the Triple Helix at a top university should combine (1) high quality teaching, (2) world class research, and (3) modern management. By the high quality teaching one means actual, fundamental and inter-disciplinary education mainly aimed to the needs of students and society, not just to the needs of professors doing their job. By the world class teaching one means that every teacher should also be a good researcher simultaneously, because only a good researcher has a chance to be a good teacher in his special field (the "first hands" principle). And by the modern management one means the joint efficient management by professors and bureaucrats at the university level, including their joint participation in working out the long-term policies at the university.

It is no secret that teaching is not the priority for a vast majority of university professors, even in the world-leading universities. High quality teaching is not very rewarding, is very time-consuming, and is not easy indeed. So, it is often (but not in public!) merely considered as the necessary burden (like job-for-money) by the teachers. Instead, the leading university professors usually invest much more their efforts either into their research, contributing to their scientific achievements, prestige, and grants, or into the university management, contributing to their administrative career. It is not bad by itself. However, each professor should contribute to (1), (2), and (3), and the more he/she contributes in total, the more he/she should get as a reward. For instance, in our university in Tokyo, every professor's performance during each academic year is judged by four factors, namely, (1), (2), and (3), as well as his/her (unpaid) contribution to society, in addition (see Section Impact on 
Industry and Society in this paper). No record in either of those four positions will have negative consequences to a staff member after evaluation, but an outstanding record at a single position will not be honored in Japan also.

To conclude this Section, it is worth of briefly addressing successful strategies for reaching the Triple Helix goals at auniversity, along the lines formulated above. Of course, there can be many strategies, based on a particular environment. However, there should be also some common features. The author calls them the triple-C strategy (it is the original concept of three Russian K's also: Компетентность, Конкуррентноспособность, Кооперация). The first $\mathrm{C}$ means Competence, the second $\mathrm{C}$ means Competitiveness, and the third $\mathrm{C}$ means Cooperation. Those three C's represent the necessary conditions for success.

\section{Innovations in a University}

An innovation is always concrete. Usually, it is just a small improvement of the existing system, but a sum of such improvements often results in very sophisticated products. It is highly desirable to offer a complete (finished) product, whenever it is possible (in Russian, they say "pod kljuch"), because it simultaneously means taking full responsibility for its quality. And it has the long tradition in Japan, where the main industrial groups produce practically everything, and always offer ready products to their customers. A university should be also a "full service" product for the society, by offering high quality teaching (1) to its students, high quality research results (2) for the needs of science and industry, with efficient management (3), being accountable for money spent on all that.

In the old past, science was a small scale personal pursuit for a few. Today's science is a huge enterprise comprising many well-paid professional people and having close ties to governments and industries, with a peer-review system of evaluation. A globalized economy and modern information technologies created a highly interconnected world that requires global thinking and local handling. It represents huge challenge to the universities too, especially as regards teaching young generations and offering technological and scientific solutions to industry and society.

Getting new results in science is always an innovation by definition. Innovations in teaching may include offering an unusual but actual course of lectures or seminars, or using unusual teaching tools. For example, the author offered a "life wisdom" seminar to the students of Tokyo Metropolitan University (there are about 70 seminars of that type, run by the professors who are over 50 years old), A professor is free to choose a subject outside of the official curriculum. In the seminars run by the author, students were giving presentations about their choices of personal life strategy for themselves, including jobs, politics, family, communication, and even pension issues, up to buying a house, getting married and educating kids. Increasing personal wisdom of students by comparing very different life stories and defending your own story is not about substituting their parents. It is about how to make educated personal choices in life, by learning specific examples.

Even management can be innovative too. For instance, in Japan after the World War II, when the country was in ruins, Japanese government asked about a hundred people from the intellectual elite to figure out economical, technological, and scientific policies for a future. Actually, they put those people into a remote place in the mountains, without any connection with the outside world, for a month. The result of implementation of those policies is now well known in the world as the technological wonder of Japan. Of course, strategic planning and making the rules is a continuous process, and they are doing it very well in Japan. 
However, the bureaucracy follows the rules imposed, so that it is very important for success of the Triple Helix at a university that the rules are adequate, thus making possible a close cooperation of professors and bureaucrats.

\section{Impact on Industry and Society}

The industry demand for applied research is obvious. It is less obvious why a fundamental research is also needed. It is well known that fundamental science is a basis for applied science. However, the author would like to stress here yet another significance of the fundamental research with participation of students.

To give an example, the author conducts research in the very advanced fundamental science with his students, namely, in theoretical cosmology and string theory.

It is not going to have practical applications any time soon. Nevertheless, most of the former students of the author (in Russia, USA, Germany, and Japan) did not have much trouble to get a job outside of the university. Actually, only about 1 out of 10 became a researcher or a professor. Some of the former students are now working for Google, Microsoft, Siemens, Canon, and Mitsubishi, outside physics. Once the author had a conversation with the CEO of the Mitsubishi Corporation in Japan. He told that they (Mitsubishi) did not much care of subjects of the university studies of their recruits, because they usually sent them to internal training for the first six months at the companyany way. What they (Mitsubishi) needed are the properly "formatted brains" who are capable of independent thinking and innovations, and are globally minded. But it is precisely what most of my former students got by studying theoretical physics!

It is of no surprise that the teaching curriculum at universities is often academically oriented and formal. It is good for science but is not necessarily good for industry and society, because most of university graduates will not go to science. And there are not so many very talented (and outstanding) students also. Therefore, there should be some alternatives to academic studies, especially for those students who want to be employed in industry or in business but do not have experience in the job. It is no secret that a successful recruiting is much more likely for those who already have job experience, but one has to get a job first (it is known as the Catch-22 in the West). To break this circle, new ways of the university education are needed, such as the new dual system in Germany, which is based on the 3-month-long lectures plus 3-months-long "praktika" at a company during each semester for business students. For example, a daughter of the author was studying international business in the dual system that is also three-national and three-lingual (i.e., at three universities in three different countries, and in three different languages) in Europe.

All that implies more transparency and more openess (friendly environment) of a modern university to a general public, in order to increase public trust and awareness in what is going on at the universities, not to mention to make them more attractive to everyone. In other words, a university should be deeply involved into public relations, both locally and nationally and, perhaps, even internationally. There are many ways of doing that, thus having a huge area for innovations. For example, at our University in Tokyo we are doing several public programs, such as Open Labs, Open Classes, Open Campus, and Open University lectures to a general public on a regular basis. A close cooperation with local high schools in the Tokyo area is also one of our priorities.

\section{Conclusion}

Though this paper is very brief, it offers the clear starting points for further discussion and development, 
and is supported by the real examples. The author refers to Chomsky (2015) and Bendukidze (2013) for more aggressive opinions. We welcome global discussion about those actual issues inside the academic community. In our global forums of the Russian-speaking science and technology professionals-see RU-SCI-TECH ${ }^{1}$ and RASA $^{2}$ —one can find more specific proposals also (mainly in Russian, though).

\section{References}

Bendukidze, K. (2013). Nobody needs diploma of high education. Retrieved from http://forbes.ua/nation/1350373-kaha-bendukidze-diplomy-o-vysshem-obrazovanii-nikomu-ne-nuzhny

Chomsky, N. (2015). The death of American universities. Retrieved from $\mathrm{http} / / /$ readersupportednews.org/opinion2/277-75/29348-the-death-of-american-universities

Etzkowitz, H. (2008). The Triple Helix: University-Industry-Government innovation in action. Routledge: New York and London.

\footnotetext{
1 Association of Russian-speaking Science and Technology Professionals (RU-SCI-TECH). Retrieved from http://ru-sci-tech.org/.

2 Russian-speaking Academic Science Association (RASA). Retrieved from http://www.dumaem-po-russki.org/.
} 